Acta Technologica Agriculturae 3

Nitra, Slovaca Universitas Agriculturae Nitriae, 2017, pp. 74-77

\title{
TURBINE MODIFICATION OF NUOVO PIGNONE GAS TURBINE
}

\author{
Dominik GAŠPAROVIČ ${ }^{1 *}$, Marián VÝŽINKÁR ${ }^{1}$, Jozef ŽARNOVSKÝ ${ }^{1}$, Jan BLATA ${ }^{2}$ \\ ${ }^{1}$ Slovak University of Agriculture in Nitra, Slovak Republic \\ ${ }^{2}$ VŠB - Technical University of Ostrava, Czech Republic
}

\begin{abstract}
This paper deals with the environmental aspects of combustor modification on Nuovo Pignone gas turbines. The mentioned company is engaged in the transport of natural gas to the Slovak Republic and further to other European markets. Legislation considering emissions is getting stricter every year. Original Nuovo Pignone gas turbines would not be able to meet the required emission limits for $\mathrm{NO}_{x}$ and $\mathrm{CO}_{r}$ determined by legislation. Therefore, the company decided to modify seven gas turbines. Due to this reason, the combustion sections had to be replaced with a dry low emission system. These modifications were aimed at improvement of impacts of temperature on the emissions of $\mathrm{NO}_{\mathrm{x}}$, since the $\mathrm{NO}_{\mathrm{x}}$ emissions are defined as thermal (there is an increase in emissions with the increase in temperature). Emissions were monitored continuously by an emission monitoring system (these data are continuously sent to the Office of Environment) and manually by a HORIBA PG-250 analyser. Gas delivery point is located in the flue pipeline, and data was processed by means of PC after reaching this point. The results lead us to conclusion that modification was an efficient and good solution in terms of economy, because this solution reduced emissions (from $300 \mathrm{mg} \cdot \mathrm{m}^{-3}$ to $50 \mathrm{mg} \cdot \mathrm{m}^{-3}$ ) and contributed to meeting of the stricter emission limits (from $370 \mathrm{mg} \cdot \mathrm{m}^{-3}$ to $100 \mathrm{mg} \cdot \mathrm{m}^{-3}$ ). Monitoring of the impacts of growing performance of equipment on emissions represents a possibility for further development of science in this field.
\end{abstract}

Keywords: analyser; diagnostics; emission; limit; measurement

In recent years, there have been more and more significant changes in the introduction of new technologies, which contribute significantly to the reduction of emissions distributed into the atmosphere by technological equipment (Pet'ková, 2010; Vitázek et al., 2014). The requirements for limits are constantly being updated and are always becoming stricter. The issue of the possibilities of emission reduction via technology equipment is highly topical (Solin, 2015; Zelenický, 1995; Šístková, 2016). This paper is focused on the possibilities of emission reduction from technological equipment used for transport of natural gas via gas combustors with Dry Low Emissions (DLE) system modification - the original combustion sections were replaced with DLE sections (Žarnovský et al., 2009).

The main aim of the gas turbine Nuovo Pignone T $23 \mathrm{MW}$ modification is the replacement of the current combustion system with a highly efficient combustion system using the DLE system due to stricter emission limits for these sources of pollution of $\mathrm{NO}_{\mathrm{x}}$ and $\mathrm{CO}_{\mathrm{r}}$

\section{Material and methods}

This part of the paper describes the equipment and methods used for the DLE modification of original combustors.

The DLE combustion principle itself is based on the premixing of air with the fuel before burning with the aim to achieve a reaction temperature lower than the temperature at which the great amount of $\mathrm{NO}_{\mathrm{x}}$ emissions is produced.
The DLE system is composed of several combustion devices which are installed on the gas generator. Each combustion chamber accurately controls the combustion temperature of the mixture of air and fuel. The dependence of emissions on the increasing temperature was determined the main benchmark (Kiss, 2002; Soares, 2008; Forsthoffer, 2011).

\section{Characteristics of the original equipment of Nuovo Pignone T $23 \mathrm{MW}$ gas turbine}

Nuovo Pignone is a turbo machine with a nominal mechanical power of $23 \mathrm{MW}$.

The main parts of the equipment are:

1. Gas generator LM 2500 SAC - is a gas turbine with open cycle. It is used for the production of hot gases that drive a power turbine. There are 30 fuel nozzles along the circumference of the combustion chamber; they form a swirl flow and provide flame stability (Solin, 2015; Amaral, 2006).

2. Power turbine PGT 25 (Fig. 1) - is a two-steps turbine. It is used for the production of torque energy of the hot gases supplied by the gas generator. The gas generator with the power turbine contains a gas turbine PGT 25 (Žarnovský et al., 2009).

3. Gas compressor $602 \mathrm{PCL}$ - this is a two-steps compressor with tangential input and gas output. The compressor is a single-casing machine, barrel type with a vertical parting plane. The gas compressor is driven by a power turbine via a claw clutch (Boyce, 2012; Pet'ková, 2010). 


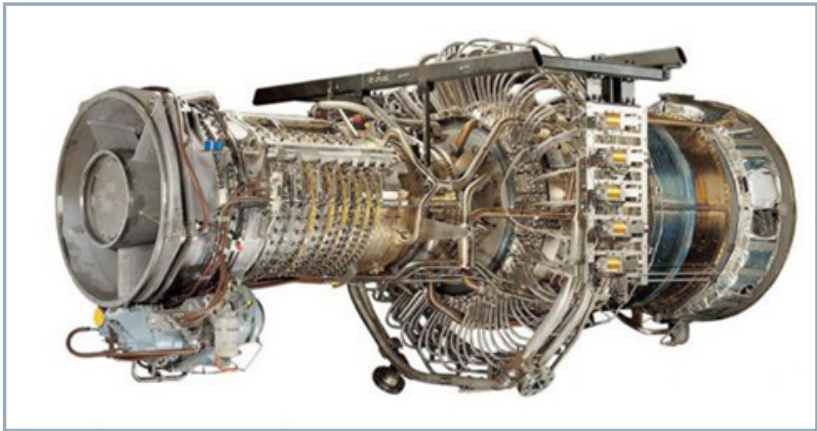

Fig. 1 Gas turbine PGT 25 DLE Source: Pet'ková, 2010

\section{Emission limits for Nuovo Pignone gas turbine}

Until recently (until 31 December 2015), the valid emission limits for the Nuovo Pignone T $23 \mathrm{MW}$ gas turbine were $370 \mathrm{mg} \cdot \mathrm{m}^{-3}$ for $\mathrm{NO}_{\mathrm{x}}$ and $100 \mathrm{mg} \cdot \mathrm{m}^{-3}$ for $\mathrm{CO}$. New legislation adopted the stricter emission limits that came into force since the 1 January 2016 and it was necessary to deal with this change. Finally, it was concluded that the best solution is to replace the original combustion section of turbo equipment with the DLE system sections (Kopný, 2004; Zelenický, 1995).

\section{Monitoring equipment HORIBA PG-250}

The portable equipment HORIBA PG-250 was used for monitoring; italso includesa system for sampletreatment, which is used in the measurement of stationary systems. The analyser PG-250 (Fig. 2) performs the following operations: backing up the data for continuous measurement (Emission Monitoring System - EMS); the measurement of combustion efficiency; and adjusting of combustion processes. The analyser contains the complete equipment necessary for sample treatment: gas pump; electric cooler for gas; gas converter $\mathrm{NO}_{2}-\mathrm{NO} ; \mathrm{O}_{3}$ source for chemiluminescent reaction and preparation of reference gas (Solin, 2015; Eustream, 2005).

\section{Monitoring process}

While monitoring the concentrations of $\mathrm{NO}_{\mathrm{x}}$ and $\mathrm{CO}$ for the Nuovo Pignone T 23 MW gas turbine equipment, the delivery point was located in the fuel pipe between the engine room and chimney. A nipple with a hole has been

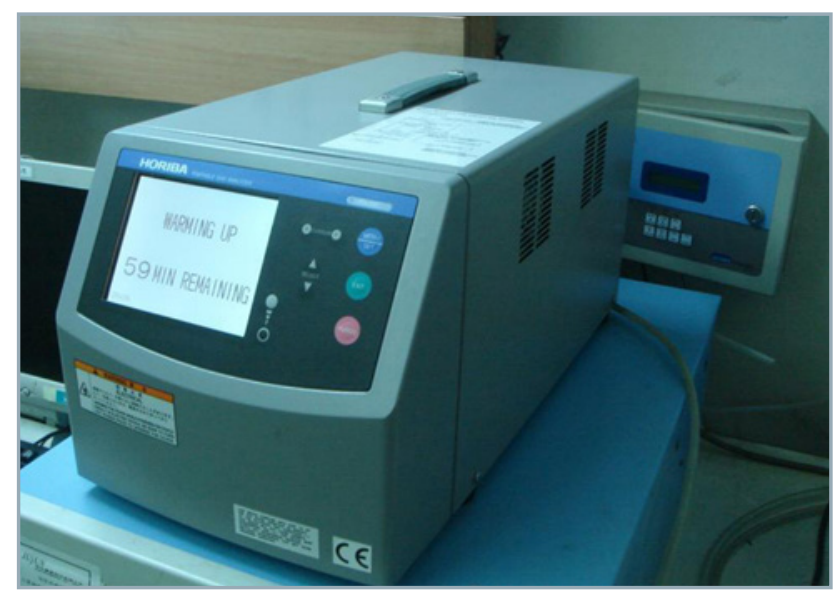

Fig. 2 Gas analyser HORIBA PG-250 Source: Solin, 2015 prepared here in order to insert the sample probe. Sampling was carried out by means of a sample probe with a length of $1.500 \mathrm{~mm}$. The measurements were performed at a power range from $15 \mathrm{MW}$ to the maximal power allowed by the device operating mode. In this point, it was necessary to maintain the identical duration of each measuring point without changes in the speed mode; this process took 30 minutes. Then, the sample was transported to portable system and it was subsequently cooled and dehydrated. The dry sample was moved to the analyser, where the emission values were measured. Afterwards, the data was transferred to the computer and the software converted these values to the final weight value by means of volume.

\section{Results and discussion}

The experiments, which were carried out during the verification of guaranteed machine parameters directly at the compressor station, were used for the result processing. The measurement was carried out by means of the emission monitoring system HORIBA PG-250.

\section{Characteristics of the modified Nuovo Pignone T 23 MW gas turbine equipment}

The modified combustion chamber of an annular type works on the lean-premix principle (with an excess of air). Combustion temperature is evenly distributed and maintained at a low level; therefore, the concentration of $\mathrm{NO}_{x}$ emissions is low even at maximal power. The modification affects the following machine parts of the Nuovo Pignone $T$ 23 MW gas turbine:

- replacement of the DLE gas generator,

- replacement of the power turbine,

- modification of synthetic oil,

- modification of mineral oil,

- adjustment of the hydraulic system of the ignition device,

- adjustment of the ventilation system,

- modification of the scrubber,

- modification of the acoustic enclosure,

- modification of $\mathrm{CO}_{2}$.

\section{Measured values before modification}

Table 1 shows the recorded operating parameters that were measured during the experiment.

Table 1 Operating parameters and measured emissions before modification

\begin{tabular}{|c|c|c|c|c|}
\hline $\begin{array}{c}\mathbf{t}_{\text {Exhaust gas }} \\
\left({ }^{\circ} \mathbf{C}\right)\end{array}$ & $\begin{array}{c}\mathbf{N O}_{\mathbf{x} \text { Limit }} \\
\left(\mathbf{m g} \cdot \mathbf{m}^{-3}\right)\end{array}$ & $\begin{array}{c}\mathbf{C O}_{\text {Limit }} \\
\left(\mathbf{m g} \cdot \mathbf{m}^{-3}\right)\end{array}$ & $\begin{array}{c}\mathbf{N O}_{\mathbf{x r}} \\
\left(\mathbf{m g} \cdot \mathbf{m}^{-3} \mathbf{)}\right.\end{array}$ & $\begin{array}{c}\mathbf{C O}_{\mathbf{r}} \\
\left(\mathbf{m g} \cdot \mathbf{m}^{-3}\right)\end{array}$ \\
\hline 722 & 370.00 & 100.00 & 284.72 & 23.68 \\
\hline 752 & 370.00 & 100.00 & 308.97 & 19.80 \\
\hline 767 & 370.00 & 100.00 & 325.99 & 17.22 \\
\hline 812 & 370.00 & 100.00 & 372.10 & 14.16 \\
\hline
\end{tabular}

The graph (Fig. 3) showing the course of emissions at the specified operating parameters and the dependence of emissions in flue gases on temperature is based on the data provided in Table 1. 


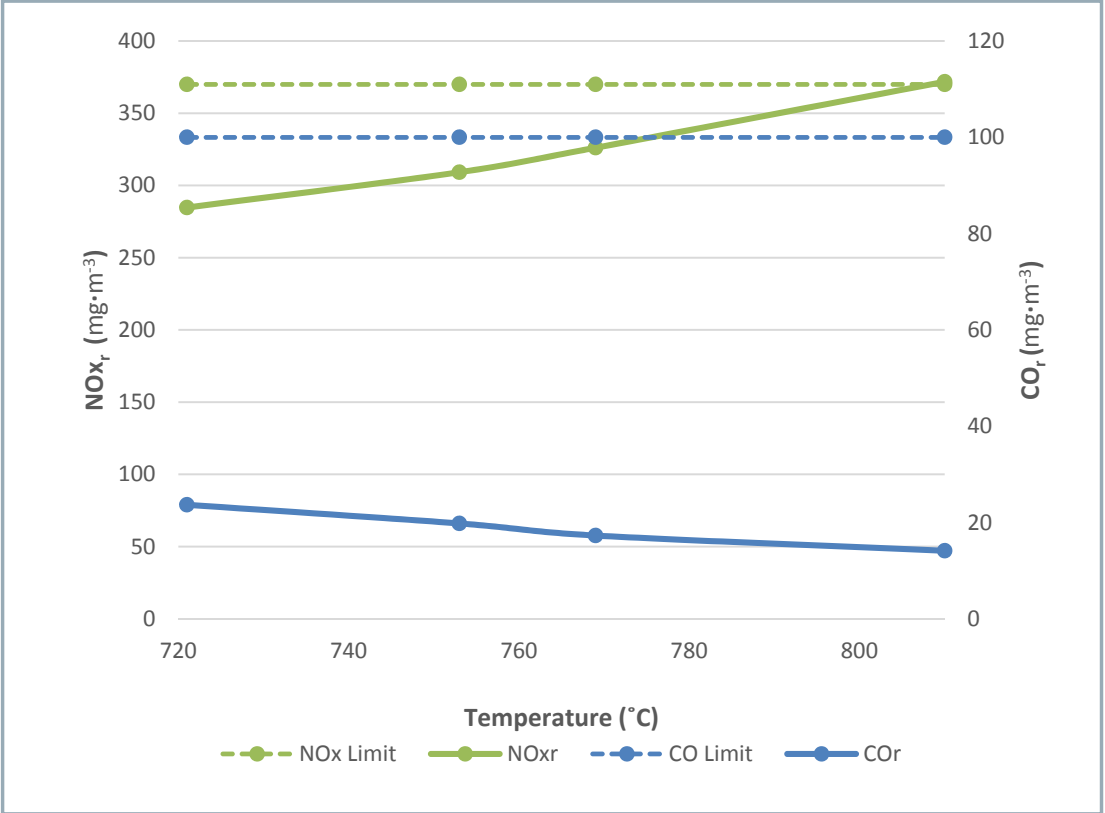

Fig. 3 The course of emissions depending on the flue gas temperature (before modification)

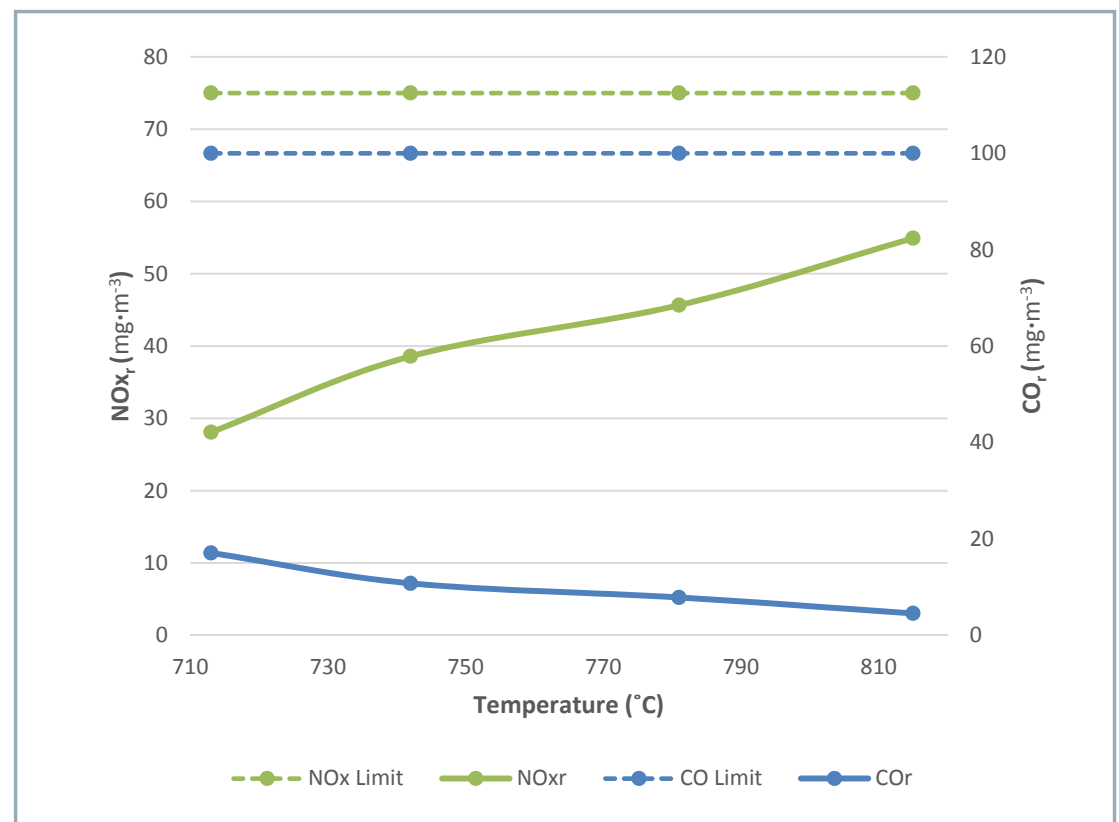

Fig. 4 The course of emissions depending on the temperature of flue gas (after modification)

Table 2 Operating parameters and measured emissions after modification

\begin{tabular}{|c|c|c|c|c|}
\hline $\begin{array}{c}\mathbf{t}_{\text {Exhaust gas }} \\
\left({ }^{\mathbf{C}} \mathbf{C}\right)\end{array}$ & $\begin{array}{c}\mathbf{N O}_{\mathbf{x} \text { Limit }} \\
\left(\mathbf{m g} \cdot \mathbf{m}^{-3}\right)\end{array}$ & $\begin{array}{c}\mathbf{C O}_{\text {Limit }} \\
\left(\mathbf{m g} \cdot \mathbf{m}^{-\mathbf{3}}\right)\end{array}$ & $\begin{array}{c}\mathbf{N O}_{\mathbf{x r}} \\
\left(\mathbf{m g} \cdot \mathbf{m}^{-3}\right)\end{array}$ & $\begin{array}{c}\mathbf{C O}_{\mathbf{r}} \\
\left(\mathbf{m g} \cdot \mathbf{m}^{-3}\right)\end{array}$ \\
\hline 715 & 370.00 & 100.00 & 28.13 & 17.20 \\
\hline 740 & 370.00 & 100.00 & 38.69 & 10.82 \\
\hline 784 & 370.00 & 100.00 & 45.63 & 7.76 \\
\hline 817 & 370.00 & 100.00 & 54.95 & 4.58 \\
\hline
\end{tabular}




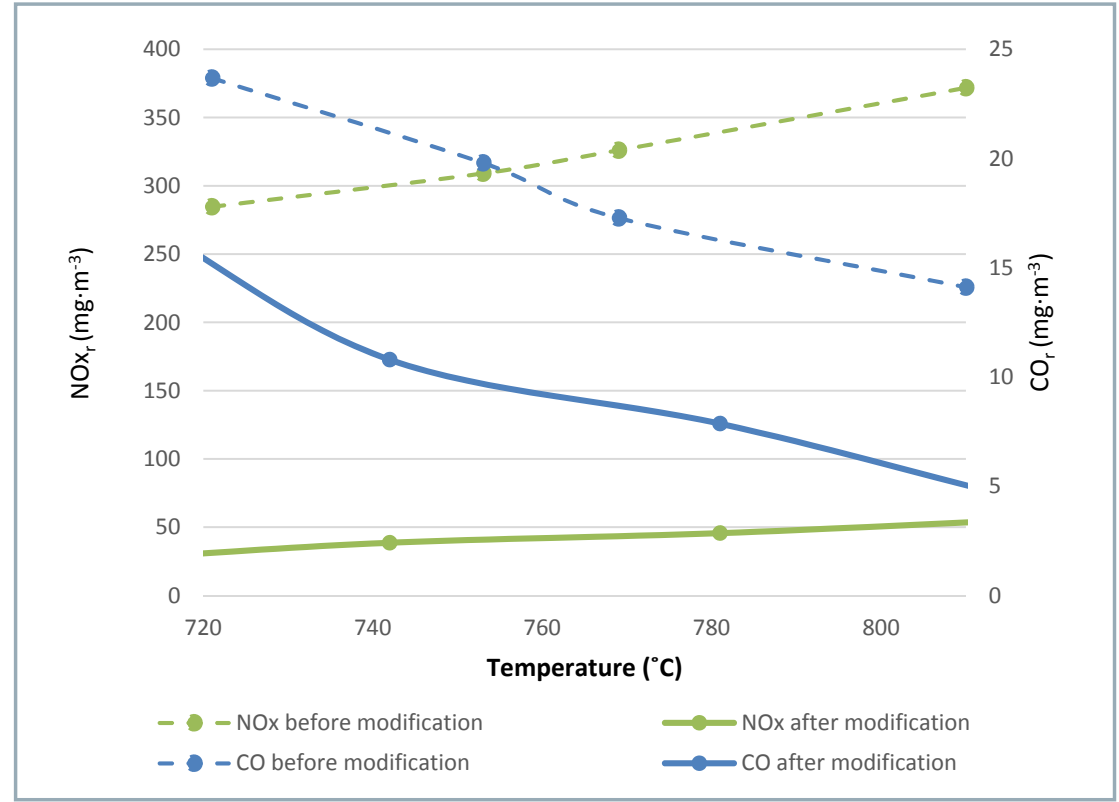

Fig. 5 The course of emissions before and after modification

experiment proved the claim that increasing temperature has a positive effect on the $\mathrm{CO}_{\mathrm{r}}$ emission production since this emission type is a product of incomplete combustion at low temperatures. This statement is demonstrated in the work by Šesták (2007), who also observed the emission parameters of gas plants. Comparing the results, we can conclude conformity; however, this study also shows that lower $\mathrm{CO}_{\mathrm{r}}$ emission production was achieved in the modified technology system at the same temperature than in the original combustion technology. This paper clearly shows the relation between the reduction of the $\mathrm{NO}_{\mathrm{x}}$ emission production and the modification of combustion chamber system with DLE. Baláž (2011) also addresses the modification in this manner, because his research also shows a significant reduction of $\mathrm{NO}_{\mathrm{x}}$ emission production after modification. Methods for $\mathrm{CO}_{r}$ control were observed by Mališ (2007); however, he dealt with them only theoretically.

All in all, it can be stated that the implementation of modifications in the turbo Nuovo Pignone gas turbine was a legitimate solution to the problem of high $\mathrm{NO}_{x}$ emission production; this step was suggested in order to reduce the additional $\mathrm{CO}_{\mathrm{r}}$ emission production (since the plant was able to meet the limits of this emission type even before modification instalment), and thus to reduce the impacts of these devices on the environment.

\section{References}

AMARAL, L. O. 2006. Machinery Failure Analysis Handbook. Houston, Texas: Gulf Publishing Company. ISBN 978-1-933762-08-1.

BALÁŽ, M. 2011. Low-Emission Combustion Chamber (in Slovak: Nízkoemisná spal'ovacia komora). Bratislava: SUT, 127 pp. BOYCE, M. P. 2012. Gas Turbine Engineering Handbook. Fourth ed., 1000 pp. ISBN 978-012-383842-1.

EUSTREAM, A. S. 2005. LM2500 + DLE GE Industrial Aero Derivative Gas Turbines: Proprietary information.

FORSTHOFFER, W. E. 2011. Forsthoffer's Best Practice Handbook for Rotating Machinery. Boston: Butterworth-Heinemann. 672 pp. KISS, G. 2002. Increasing of the compression ratio of the compressor station 01: research report (in Slovak: Zvyšovanie kompresného pomeru kompresorovej stanice 01: výskumná správa). Košice: Eustream. 122 pp. KOPNÝ, R. 2004. Operation of gas turbines in the SPP a. S., noise and emissions aspects of the proposed solutions (in Slovak: Prevádzka plynových turbín SPP a. S., hluk a emisné aspekty navrhnovaného riešenia). In Slovgas, no. 3.

MALIŠ, J. 2007. Methods of reducing emissions of carbon dioxide. Brno: UT. 73 pp. PEŤKOVÁ, V. 2010. Theory and application of the selected methods of technical diagnostics (in Slovak: Teória a aplikácie vybraných metód technickej diagnostiky). Košice: TU, pp. 44-45. ISBN 978-80-553-0483-0.

SOARES, C. 2008. Gasturbines. ButterworthHeineman. 750 pp. ISBN 978-0-7506-7969.

SOLIN, L. 2015. The environmental aspects of the combustion chamber modifications to the devices (in Slovak: Environmentálne aspekty úprav spal'ovacích komôr a zariadení). Nitra: SUA. 54 pp.

ŠESTÁK, M. 2007. The use of statistical methods of quality control: dissertation thesis (in Slovak: Využitie štatistických metód $v$ riadení kvality). Nitra: SUA. 145 pp. ŠÍSTKOVÁ, M. - PŠENKA, M. - CELJAK, I. BARTOŠ, P. - MIHINA, Š. - PAVLÍK, I. 2016. Noise emissions in milking parlours with various construction solutions. In Acta Technologica Agriculturae, vol. 19, no. 2, pp. 49-51.

VITÁZEK, I. - KLÚČIK, J. - PINTER, T. MIKULOVÁ, Z. 2014. Gas emissions in combustion of biofuel. In Acta Technologica Agriculturae, vol 17, no. 3, pp. 75-79.

ZELENICKÝ, M. 1995. Regulation for the operation of 23 MW T Nuovo Pignone (in Slovak: Regulačný predpis pre prevádzku 23 MW NUOVO PIGNONE).

ŽARNOVSKÝ, J. - PEŤKOVÁ, V. - RUŽBARSKÝ, J. 2009. Diagnosis of machinery and equipment (in Slovak: Diagnostika strojov a zariadení). Nitra: SUA. ISBN 978-80-552-0300-3. the distortion of the environment of all organisms, including humans. 